\title{
IAP2016 国際学会報告
}

日本膵臓学会国際交流委員会委員長

高折 恭一

はじめに

第 20 回国際膵臓学会 $(I A P) \cdot$ 第 47 回日本膵蔵 学会 (JPS) ・第 6 回アジアオセアニア膵臓学会 (AOPA) 合同大会（以下, IAP2016 とさせてい ただきます）は，下瀬川徹会長（IAP）, 伊佐地秀 司会長 (JPS), 杉山政則会長 (AOPA) のもと, 2016 年 8 月 4 日から 7 日まで仙台国際センターで 開催され, 1100 名をこえる国内外からの参加があ り，成功裏に終了いたしました (写真 1$)$. 多くの 会員の先生方が大会に参加され, 実りある学術集 会として合同大会を盛り上げていただいたものと 存じます。この合同大会は, 日本膵臓学会から世 界に向けて, その業績を発信する場でもありまし た.ここでは, 国際交流の観点から, 合同大会に ついてご報告させていただきたく存じます.

\section{IAP2016 開催の経緯}

IAP の正式名称は International Association of Pancreatology で, 膵臓の機能と病態についての 基礎的及び臨床的な理解を深めることを目的とし て, 1984 年に最初の会合が行われ，1985年に正式 に設立されました，表 1 の通り，今回を含めて 20

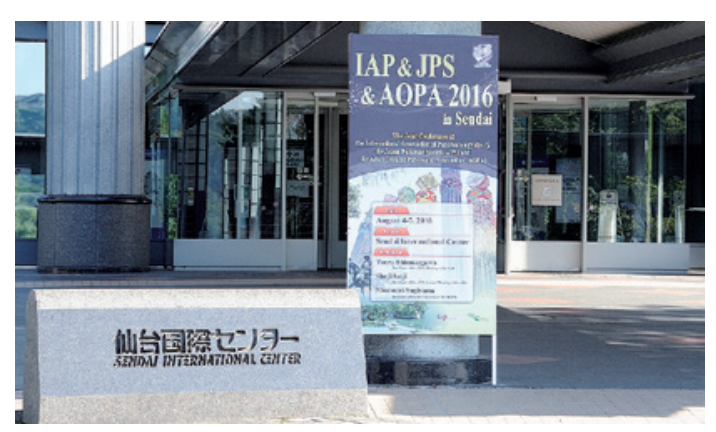

写真 1 会場となった仙台国際センター
回の大会が開催されています。初期には 2 年毎の 開催で, 早くも 1990 年には土屋凉一先生が, 第 4 回 IAP大会を主催されています. わが国に西洋医 学が導入された長崎の地で, 日本の膵臓学を本格 的に世界に発信する初めての機会が設けられたこ との歴史的意義は非常に大きかったと思います。 その後, 1998 年に竹内正先生 (東京), 2004 年に 松野正紀先生(仙台), 2010 年には田中雅夫先生 (福岡) が, それぞれIAP PresidentとしてIAP 大会を主催されました。これまで, IAP は日本膵 臟学会, American Pancreatic Association(APA), European Pancreatic Club (EPC) の 3 つの学会 が柱 (ピラー) となって運営されてきました. IAP

表 1 IAP 大会の歴史

\begin{tabular}{|c|c|c|}
\hline 回 & 開催場所 & 開催年 \\
\hline $1^{\mathrm{st}}$ & Estoril, Portugal & 1984 \\
\hline $2^{\text {nd }}$ & Sao Paulo, Brazil & 1986 \\
\hline $3^{\text {rd }}$ & Verona, Italy & 1988 \\
\hline $4^{\text {th }}$ & Nagasaki, Japan & 1990 \\
\hline $5^{\text {th }}$ & Athens, Greece & 1992 \\
\hline $6^{\text {th }}$ & Chicago, USA & 1994 \\
\hline $7^{\text {th }}$ & Mannheim, Germany & 1996 \\
\hline $8^{\text {th }}$ & Tokyo, Japan & 1998 \\
\hline $9^{\text {th }}$ & Chicago, USA & 2000 \\
\hline $10^{\text {th }}$ & Heidelberg, Germany & 2002 \\
\hline $11^{\text {th }}$ & Sendai, Japan & 2004 \\
\hline $12^{\text {th }}$ & Chicago, USA & 2006 \\
\hline $13^{\text {th }}$ & Lodz, Poland & 2008 \\
\hline $14^{\text {th }}$ & Fukuoka, Japan & 2010 \\
\hline $15^{\text {th }}$ & Cochin, India & 2011 \\
\hline $16^{\text {th }}$ & Miami, USA & 2012 \\
\hline $17^{\text {th }}$ & Seoul, Korea & 2013 \\
\hline $18^{\text {th }}$ & Southampton, UK & 2014 \\
\hline $19^{\text {th }}$ & Shanghai, China & 2015 \\
\hline $20^{\text {th }}$ & Sendai, Japan & 2016 \\
\hline $21^{\mathrm{st}}$ & Buenos Aires, Argentina（予定） & 2017 \\
\hline
\end{tabular}


大会は 2 年毎にピラー学会が順番に開催する不文 律があり, 日本では 6 年毎にIAP が開催されてき たわけです。しかし，2010年以降は，中国・韓 国・インド・南米諸国等からも, IAP に積極的に 関与する動きが出てきました。そここで, IAP 大会 を毎年開催とし, 奇数年にはピラー学会以外の国 で開催されるようになりました（表 1)。一方，隅 数年にピラー学会が IAP 大会を担当する不文律 には流動的なところもあり，6年毎に日本で開催 することが保証さているわけではありません，日 本でIAP大会を開催するためには, IAPの執行機 関である Council の承認を得る必要があります。 すなわち, IAP Presidentは, 会則に則り Council によって President-electとして選ばれ, その 2 年 後にPresident に就任, さらにその 2 年後に IAP 大会を主催することが決められています. Council Meeting は通常, 年 2 3 回開催されますが, 多く の国から代表が参加するなか, 日本膵蔵学会の存 在感を示すことは極めて重要です，そこで，日本 膵藏学会から多くの役員の先生方がCouncil Meetingに出席し, 国際交流に尽力されています (表 2). また, IAP は各国の膵臓学会とダブルメ ンバーシップの制度を設けており, 日本は最も会 員数の多い国となっています。そのような努力の 甲斐あって, 2012 年の IAP Council Meeting にお いて, 下瀬川徹先生が President-electに選出され るという経緯で, IAP2016が仙台で開催されるこ とになった次第です、日本膵臓学会会員の皆さま には, IAP ダブルメンバーシップをはじめとする 国際交流事業にご協力を賜り，この場を借りて厚 く御礼を申し上げます。

\section{国際コンセンサス会議}

今回の合同大会の目玉とも言える特長として, 重要なテーマに関する国際コンセンサス会議を多 く開けたことがあげられると思います。今回行わ れたのは, 以下の 5 つのテーマです.

1. Consensus for treatment of autoimmune pancreatitis

2. International consensus on PNET

3. International consensus on the management of IPMN
表2 IAP Councilの参加メンバー (2016年 10 月 15 日現在)

\begin{tabular}{l} 
Executive Committee \\
Suresh Chari, Rochester (President) \\
Tooru Shimosegawa, Sendai (Past-President) \\
Thomas Gress, Marburg (President-elect) \\
Pramod Garg, New Delhi (Secretary) \\
Santhi Vege, Rochester (Treasurer) \\
Council \\
Minoti Apte, Sydney \\
Marc Besselink, Amsterdam \\
Richard Charnley, Newcastle upon Tyne \\
Marco del Chiaro, Stockholm \\
Luca Frulloni, Verona \\
Junji Furuse, Tokyo \\
Natalia Gubergrits, Donetsk \\
Peter Hegyi, Szeged \\
Myung-Hwan Kim, Seoul \\
Sun-Whe Kim, Seoul \\
Wataru Kimura, Yamagata \\
Min Li, Oklahoma City \\
Marcel Machado, Sao Paulo \\
Julia Mayerle, Greifswald \\
Kazuichi Okazaki, Osaka \\
Grazyna Rydzewska, Warsaw \\
William (Bill) Steinberg, Rockland \\
Robert Sutton, Liverpool \\
Yoshifumi Takeyama, Osaka \\
Hiroki Yamaue, Wakayama \\
Huaizhi Wang, Chongqing \\
Observer \\
Kyoichi Takaori, Kyoto (representing Pancreatology) \\
Maria Vaccaro, Buenos Aires (representing IAP2017) \\
\hline
\end{tabular}

4. International consensus on borderline resectable pancreatic cancer

5. What is early chronic pancreatitis and why is diagnosis important?

それぞれ，わが国が世界の研究をリードしてい る分野であり, 各国の研究者とともに活発なディ スカッションが行われました（写真 2 ).

\section{モーニングセミナー}

国際交流委員会では，今回からの新しい試みと して，ボトムアップに国際交流を促進することを 目的に, 英語発表・英文論文執筆のスキルアップ を目指したモーニングセミナーを開催しました。 


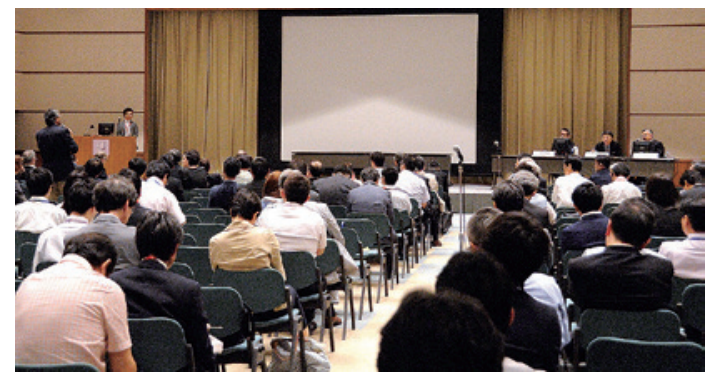

写真 2 国際コンセンサス会議におけるディスカッション (International consensus on the management of IPMN)

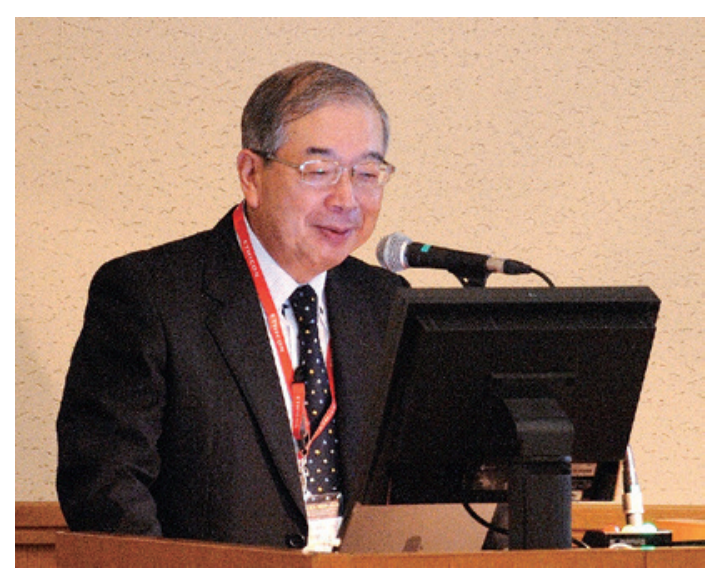

写真 3 モーニングセミナーで英文論文の書き方と「他 力」について講演される伊佐地秀司先生

国際的に活躍されている杉山政則先生と伊佐地秀 司先生が, 合同大会会長として超多忙ななか, 講 師を引き受けてくださいました（写真 3 ). 早朝に もかかわらず, 多数の会員が参加し, 熱心にメモ を取っておられたのが印象的でした。ご好評をい ただきましたので, 来年度以降の日本膵蔵学会で も引き続きモーニングセミナーを開講していきた いと存じます.

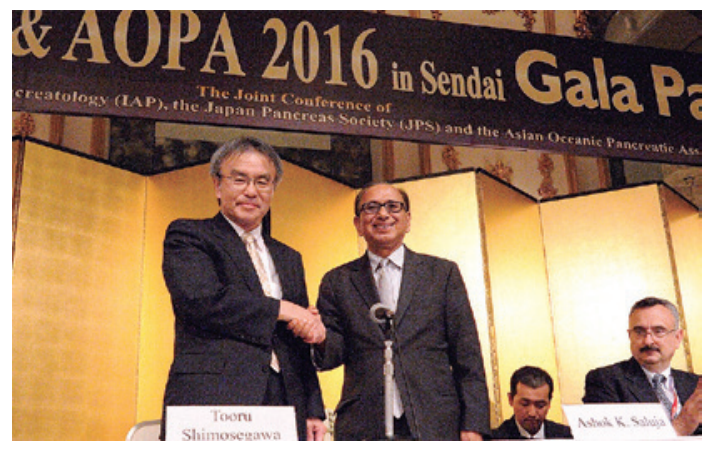

写真 4 日本膵臓学会・APA 姉妹学会締結調印式で握 手される下瀬川徹先生と Ashok Saluja 先生

\section{日本膵臓学会・APA 姉妹学会締結調印式}

今回の合同大会では, 昨年合意された日本膵臓 学会・APA 姉妹学会締結に関する Memorandum of understanding (MOU) の調印式がGala Dinner に先立って行われました (写真 4$)$. 詳細について は他稿に譲りますが, 国際的な舞台である IAP2016において, 記念すべき調印式が催された ことは意義深いことであると考えます。

\section{おわりに}

会員の皆さまのご尽力のおかげをもちまして， IAP2016は国際交流の観点からも大きな成果を収 めることができました，また，大きな合同大会の 開催で東北大学大学院医学系研究科消化器病態学 分野, 三重大学大学院医学系研究科肝胆膵 - 移植 外科学, 杏林大学医学部外科学の教室員の方々は じめ主催関係者の皆さまにおかれましては, 大変 なご苦労があったことと存じます，末筆とはなり ますが, 素晴らしい国際交流の機会を提供してい ただきました関係各位に，深甚なる敬意を表し， 心より感謝申し上げます。 